\title{
Endotoxin and Cytokines Decrease Serum Levels and Extra Hepatic Protein and mRNA Levels of Cholesteryl Ester Transfer Protein in Syrian Hamsters
}

\author{
Ingibjörg Hardardóttir, ${ }^{*}$ Arthur H. Moser, ${ }^{*}$ John Fuller, ${ }^{*}$ Christopher Fielding, ${ }^{\ddagger}$ Kenneth Feingold, ${ }^{*}$ and Carl Grünfeld” \\ *Department of Medicine, University of California San Francisco and Metabolism Section, Medical Service, Department of Veterans \\ Affairs Medical Center, San Francisco, California 94121; and ${ }^{\ddagger}$ Cardiovascular Research Institute, University of California Medical Center, \\ San Francisco, California 94143
}

\begin{abstract}
Endotoxin alters the metabolism of lipoproteins, including that of high density lipoprotein (HDL). Cholesteryl ester transfer protein (CETP) facilitates exchange of HDL cholesterol for very low density lipoprotein (VLDL) triglyceride, leading to catabolism of HDL. We investigated the effects of endotoxin and cytokines on CETP in Syrian hamsters. Endotoxin induced a rapid and progressive decrease in serum CETP levels; by $48 \mathrm{~h}$ CETP had decreased to $<20 \%$ of control levels. Endotoxin also decreased CETP mRNA and protein levels in adipose tissue, heart, and muscle, the tissues with highest levels of CETP mRNA, providing a plausible mechanism for the endotoxin-induced decrease in circulating CETP. Dexamethasone did not mimic the effects of endotoxin on CETP, but the combination of tumor necrosis factor and interleukin-1 did, indicating that these cytokines may in part mediate the effects of endotoxin on CETP. The endotoxin-induced decrease in CETP may help maintain HDL cholesterol levels during infection and inflammation when increased triglyceride levels could drive the exchange of HDL cholesteryl ester for VLDL triglyceride. Maintaining circulating HDL may be important because HDL protects against the toxic effects of endotoxin and provides cholesterol for peripheral cells involved in the immune response and tissue repair. (J. Clin. Invest. 1996. 97:2585-2592.) Key words: lipopolysaccharide • immunologic factors - acute phase reaction • cholesteryl ester transfer protein $\bullet$ corticosteroid
\end{abstract}

\section{Introduction}

Infection and inflammation induce dramatic changes in plasma levels of the acute phase proteins as well as alterations in lipid metabolism that are thought to have beneficial effects in host defense $(1,2)$. Endotoxin administration, which mimics infection, stimulates the production of cytokines that mediate many of the metabolic responses to infection and inflammation. For example, endotoxin and cytokines increase serum triglycerides, predominantly in very low density lipoproteins (VLDL), by increasing hepatic lipogenesis and VLDL production and/

Address correspondence to Carl Grünfeld, M.D., Ph.D., Department of Veterans Affairs Medical Center 111F, 4150 Clement Street, San Francisco, CA 94121. Phone: 415-750-2005; FAX: 415-750-6927; E-mail: grunfld@itsa.ucsf.edu

Received for publication 3 October 1995 and accepted in revised form 30 January 1996.

The Journal of Clinical Investigation

Volume 97, Number 11, June 1996, 2585-2592 or by decreasing clearance of triglyceride-rich lipoproteins through inhibition of lipoprotein lipase (reviewed in reference 2). Endotoxin and cytokines also increase serum cholesterol levels in rodents, an effect that is due in part to an increase in the activity of hydroxymethylglutaryl coenzyme A reductase, the rate-limiting enzyme in cholesterol synthesis $(3,4)$ and a decrease in cholesterol $7 \alpha$ hydroxylase, the rate-limiting enzyme in bile acid synthesis (Feingold, K., manuscript submitted for publication).

In contrast to serum triglyceride and cholesterol levels, high density lipoprotein (HDL) cholesterol levels show small decreases after administration of endotoxin and cytokines to rodents. The decrease in HDL cholesterol levels is often accompanied by a decrease in apolipoprotein (apo) A-I (reviewed in reference 2). Because apo A-I plays a major role in HDL-mediated cholesterol efflux from cells, decreased apo A-I during infection may lead to decreased reverse cholesterol transport. In contrast, two other apolipoproteins associated with HDL are increased after administration of endotoxin or cytokines: apo serum amyloid A (apoSAA) ${ }^{1}$ and apo J. Both of these apolipoproteins may be important for regulating HDL cholesterol levels and HDL function. ApoSAA-rich HDL are rapidly cleared from plasma (5), thus increased apoSAA could contribute to endotoxin-induced decrease in HDL cholesterol levels. SAA-rich HDL are also more readily taken up by macrophages and less readily taken up by hepatocytes (6). HDL cholesterol may thus preferentially be directed to macrophages during the acute phase response.

Metabolism of HDL is also dependent on several key enzymes the activity of which are modified by endotoxin. The activity of hepatic lipase is decreased by endotoxin and inflammation (7-10). Hepatic lipase is responsible for metabolizing large triglyceride-rich HDL into smaller $\mathrm{HDL}_{2}$, which is more rapidly cleared from the circulation, and to pre $\beta_{1}$ HDL, which is believed to play a key role in mediating the transfer of free cholesterol from cell membranes (11-13). In addition endotoxin decreases the activity of lecithin:cholesterol acyl transferase (LCAT), which is responsible for esterifying free cholesterol in HDL (14-16). The decrease in LCAT activity leads to an increase in free cholesterol and a decrease in esterified cholesterol in HDL.

Cholesteryl ester transfer protein (CETP) mediates the exchange of HDL cholesteryl ester for VLDL triglycerides (17, 18). Subsequently, HDL becomes depleted of cholesterol ester and enriched in triglycerides. Hepatic lipase acts on the triglyceride rich $\mathrm{HDL}$, generating remnant $\mathrm{HDL}_{2}$, which is taken up by the liver. The effect of endotoxin on CETP has been examined in transgenic mice overexpressing the human CETP gene.

1. Abbreviations used in this paper: bw, body weight; CETP, cholesteryl ester transfer protein; i.p., intraperitoneally; LCAT, lecithin: cholesterol acyl transferase; SAA, serum amyloid A. 
In these mice, endotoxin decreases mRNA levels for CETP in the liver and CETP protein in plasma (19). However, endotoxin increased the mRNA levels for CETP in peripheral tissues in the transgenic mice. The effects of cytokines on CETP has not been studied.

We have examined the effects of both endotoxin and cytokines on expression of the native gene for CETP in Syrian hamsters. Hamsters have very low levels of mRNA for CETP in liver but higher levels in adipose tissue, muscle, and heart, which may contribute to serum levels of CETP in these animals (20). We have used the Syrian hamsters to investigate the effects of endotoxin and cytokines on lipid and lipoprotein metabolism because in contrast to other rodents, cholesterol and lipoprotein metabolism in Syrian hamsters resembles that in humans. Moreover, hamsters, unlike mice and rats, have cholesteryl ester transfer activity in plasma (21).

\section{Methods}

Materials. $\left\{{ }^{32} \mathrm{P}\right\} \mathrm{dCTP}(3,000 \mathrm{Ci} / \mathrm{mmol}, 10 \mathrm{mCi} / \mathrm{ml})$ was purchased from New England Nuclear (Boston, MA). Endotoxin (Escherichia coli 55:B5) was purchased from Difco Laboratories (Detroit, MI) and was freshly diluted to desired concentrations in pyrogen-free $0.9 \%$ saline (Kendall McGraw Laboratories, Inc., Irvine, CA). Human tumor necrosis factor (TNF)- $\alpha$ with a sp act of $5 \times 10^{7} \mathrm{U} / \mathrm{mg}$ was kindly provided by Genentech, Inc. (South San Francisco, CA). Recombinant human interleukin (IL)-1 $\beta$ with a sp act of $1 \times 10^{9} \mathrm{U} / \mathrm{mg}$ was generously provided by Immunex (Seattle, WA). Dexamethasone sodium phosphate was from Lyphomed (Deerfield, IL). Multiprime DNA labeling system was purchased from Amersham International (Amersham, United Kingdom). Mini spin columns were purchased from Worthington Biochemical Corp. (Freehold, NJ). Oligo (dt)-cellulose, type $77 \mathrm{~F}$ was purchased from Pharmacia LKB Biotechnology AB (Uppsala, Sweden). Western light chemiluminescent detection system was purchased from Tropix, Inc. (Bedford, MA). A mAb against human CETP that reacts with hamster CETP was obtained from International Immunodiagnostics (Foster City, CA), and the IgG purified on protein A-agarose was from Bio-Rad Laboratories (AffigelProtein A, MAPSII kit; Hercules, CA). Nitrocellulose was purchased from Schleicher and Schuell (Keene, NH). Kodak XAR5 film was used for autoradiography. The DNA for CETP was prepared as described (22).

Animals. Male Syrian hamsters $(\sim 100-150 \mathrm{~g})$ were purchased from Simonsen Laboratories (Gilroy, CA). The animals were maintained in a room with lights on from 6:00 a.m. to 6:00 p.m. and were provided with rodent chow and water ad lib. Animals were injected intraperitoneally (i.p.) with endotoxin, dexamethasone, TNF + IL-1, TNF, or IL-1 at the indicated doses in $0.5 \mathrm{ml} 0.9 \%$ saline or with saline alone. After administration of endotoxin, dexamethasone, or cytokines, food was withdrawn from both control and treated animals, because endotoxin and cytokines can induce anorexia. Animals were studied between $90 \mathrm{~min}$ and $48 \mathrm{~h}$ after endotoxin administration as indicated in the text.

Isolation of RNA and Northern blotting. Total RNA was isolated by a variation of the guanidinium thiocyanate method (23). Total RNA from adipose tissue was used for Northern blotting, but poly A RNA from all other tissues was isolated using oligo dT cellulose. Poly A RNA or RNA was quantified by measuring adsorption at $260 \mathrm{~nm}$. Equal amounts of RNA $(10 \mu \mathrm{g})$ were loaded on $1 \%$ agarose-formaldehyde gels and electrophoresed. The uniformity of sample applications was checked by ultraviolet visualization of the ethidium bromide-stained gel before transfer to nitrocellulose membranes. We and others have found that endotoxin increases mRNA levels of actin in liver $(4,24)$ and in adipose tissue (unpublished observations by this laboratory). Endotoxin also increases hepatic mRNA levels for cyclophilin by 2.7-fold (unpublished observations by this laboratory). The
mRNA levels of actin and cyclophilin, which are widely used for normalizing data, can therefore not be used during studies of endotoxin induction of acute phase proteins. However, the magnitude of the change in mRNA levels after endotoxin and cytokine administration and the relatively small standard error of the mean make it unlikely that the changes observed are due to unequal loading of RNA. Furthermore, the regulation of mRNA by LPS and cytokines is specific, as the mRNAs for key proteins show different degrees of induction or repression, differential induction by cytokines, different dose response curves, and tissue-specific responses (4, 16, 28-30, Hardardóttir, I., et al., manuscript submitted for publication). RNA probe hybridization was performed in $0.75 \mathrm{M}$ sodium chloride, $0.075 \mathrm{M}$ sodium citrate, $2 \%$ SDS, $10 \%$ dextran sulfate, $2 \times$ Denhardt's solution and 100 $\mu \mathrm{g} / \mathrm{ml}$ sheared salmon sperm DNA at $65^{\circ} \mathrm{C}$ overnight. Blots were washed at $42^{\circ} \mathrm{C}$ in $0.3 \mathrm{M}$ sodium chloride, $0.03 \mathrm{M}$ sodium citrate, and $0.1 \%$ SDS. All blots were exposed to $\mathrm{x}$-ray film, and bands were quantified by densitometry. Duration of film exposure was varied to allow measurements on the linear portion of the curve.

Western blotting. For the determination of CETP protein, SDSPAGE was performed as described by Clarke et al. (25) with modifications described previously (4). Serum was diluted with loading buffer before analysis on a SDS-PAGE. Tissues $(1 \mathrm{~g})$ were homogenized on ice with a Wheaton Dounce tissue grinder in $2 \mathrm{ml}$ of buffer containing $20 \mathrm{mM}$ sodium phosphate, $\mathrm{pH} 7.5,0.2 \mathrm{mM} \mathrm{NaCl}, 2 \%$ Triton $\mathrm{X}-100$, vol $/ \mathrm{vol}, 1 \%$ sodium deoxycholate, $0.2 \%$ SDS, $2 \mathrm{mM}$ diethyl $p$-nitrophenyl phosphate, $0.2 \mu \mathrm{M}$ leupeptin, and $600 \mathrm{U} / \mathrm{ml}$ aprotinin (26). After 15-min incubation on ice, the homogenate was centrifuged, and the clear infranatant was collected. Serum samples and infranatants from tissues were analyzed in the reduced state using $7 \%$ polyacrylamide gel with a $4 \%$ stacking gel. Protein was transferred to nitrocellulose $(0.2-\mathrm{mm}$ pore size). CETP protein was detected with $\mathrm{mAb}$ generated against human CETP, using the Tropix Western Light chemiluminescent detection system. After x-ray film development, band density was measured using a Biorad GS-670 Imaging Densitometer (Bio-Rad Laboratories).

Statistics. The results are expressed as means \pm SEM. Statistical significance was determined using a two-tailed Student's $t$ test.

\section{Results}

To investigate the effects of endotoxin on serum levels of CETP, Syrian hamsters were injected intraperitoneally with endotoxin $(100 \mu \mathrm{g} / 100 \mathrm{~g}$ body wt [bw]). CETP was detected by Western blotting using an $\mathrm{mAb}$ against human CETP that cross-reacts with hamster CETP (see Methods). As shown in Fig. 1, endotoxin administration markedly decreased serum levels of CETP. The CETP levels were significantly reduced $4 \mathrm{~h}$ after endotoxin administration (by 18\%) and continued to decrease, such that by $48 \mathrm{~h}$ after endotoxin administration, serum CETP levels were $<20 \%$ of control levels.

We next determined the dose response for endotoxininduced decreases in serum CETP levels at $36 \mathrm{~h}$ after treatment. As shown in Fig. 2, 10 and 100 times lower doses of endotoxin ( 1 and $10 \mu \mathrm{g} / 100 \mathrm{~g} \mathrm{bw}$ ) decreased serum CETP protein levels $36 \mathrm{~h}$ after administration. A dose of $0.1 \mu \mathrm{g} / 100 \mathrm{~g}$ bw was ineffective when studied 24 and $48 \mathrm{~h}$ after administration, indicating that the half-maximal dose of the effect of endotoxin on serum CETP levels is between 0.1 and $1 \mu \mathrm{g} / 100 \mathrm{~g}$ bw.

We then examined whether, in addition to decreasing CETP levels in the circulation, endotoxin also affects CETP protein levels in peripheral tissues. In hamsters, very low levels of mRNA for CETP are found in the liver, but adipose tissue, muscle, and heart are abundant sources (26). In addition, mRNA levels for CETP in adipose tissue and heart correlate with plasma CETP concentrations, suggesting that these tis- 


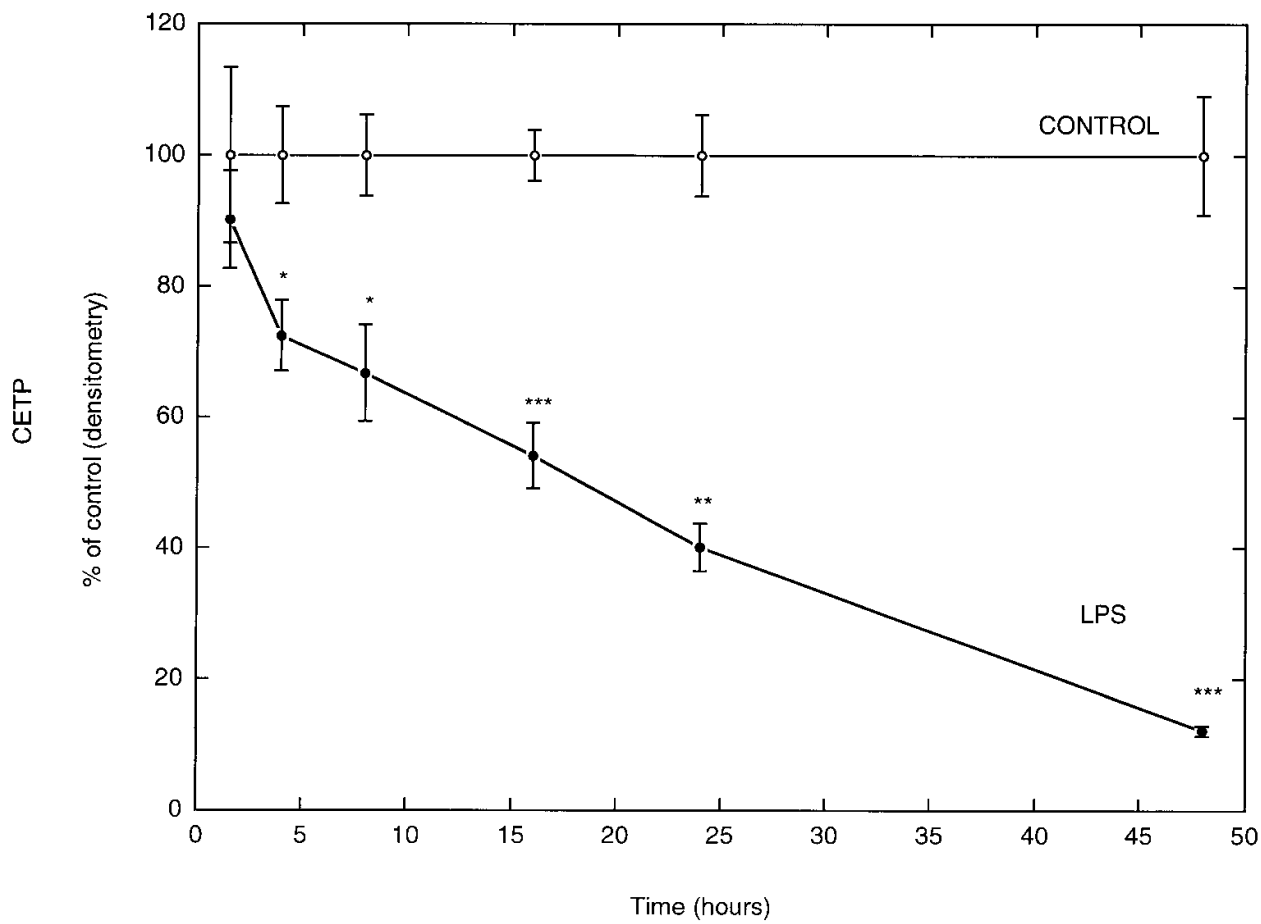

Figure 1. Time course of the effect of endotoxin on serum levels of CETP. Syrian hamsters were injected i.p. with either saline $(\bigcirc)$ or $100 \mu \mathrm{g} / 100 \mathrm{~g}$ bw endotoxin (0). At the times indicated, the animals were killed and serum CETP was measured as described under Methods. Data are presented as mean \pm SEM, $n=5 . * P<0.05$, $* * P<0.005, * * * P<0.0005$ vs. control. sues may contribute to serum levels of CETP (20). CETP protein levels in adipose tissue, heart, and muscle were measured by Western blotting after homogenization in a detergent buffer as detailed in Methods. As shown in Fig. 3, endotoxin administration significantly decreased CETP levels in adipose tissue, heart, and muscle by $50-60 \%$, suggesting that the decrease in CETP levels in the circulation may be due to decreased CETP production in these tissues.

To further determine the mechanism by which CETP protein levels are decreased, we next measured the mRNA levels for CETP in the key tissues of the hamster after administration of endotoxin. In accordance with previous reports, mRNA for CETP was not detected in the liver or spleen of the hamsters (26). RNA for CETP was, however, detected in adipose tissue, muscle, heart, intestine, stomach, and kidney. As shown in Fig. 4, $16 \mathrm{~h}$ after administration of endotoxin, mRNA levels for CETP were markedly decreased in all of these tissues.

Endotoxin induces glucocorticoids, and glucocorticoids have been shown to mediate some of the effects of endotoxin (27). In mice overexpressing the human CETP gene, cortisone administration mimics the effects of endotoxin on plasma CETP levels. Additionally, treatment with cortisone decreased

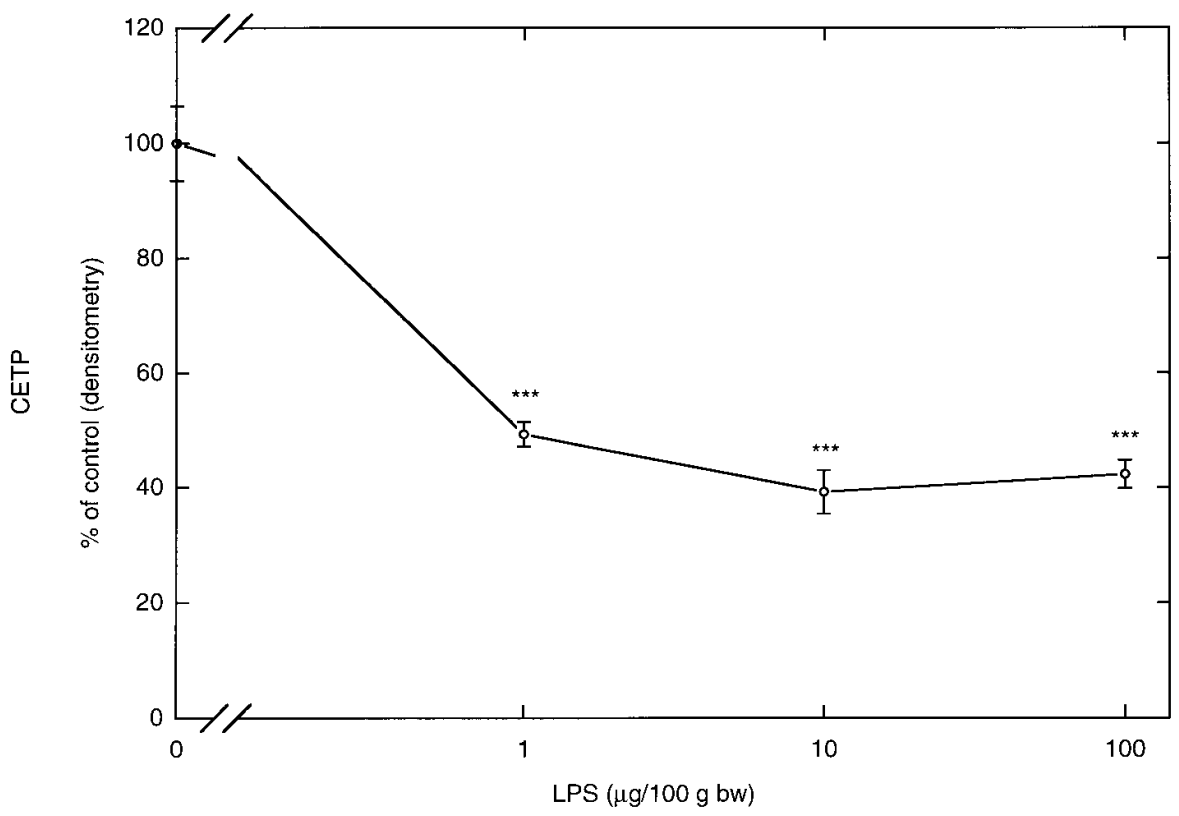

Figure 2. Dose response of the effect of endotoxin on serum levels of CETP. Syrian hamsters were injected i.p. with either saline (control) or LPS at 1,10 , or $100 \mu \mathrm{g} / 100 \mathrm{~g}$ bw. $36 \mathrm{~h}$ later the animals were killed, and serum CETP was measured as described under Methods. Data are presented as mean \pm SEM, $n=5$. ${ }^{* * *} P<0.0005$ vs. control. 


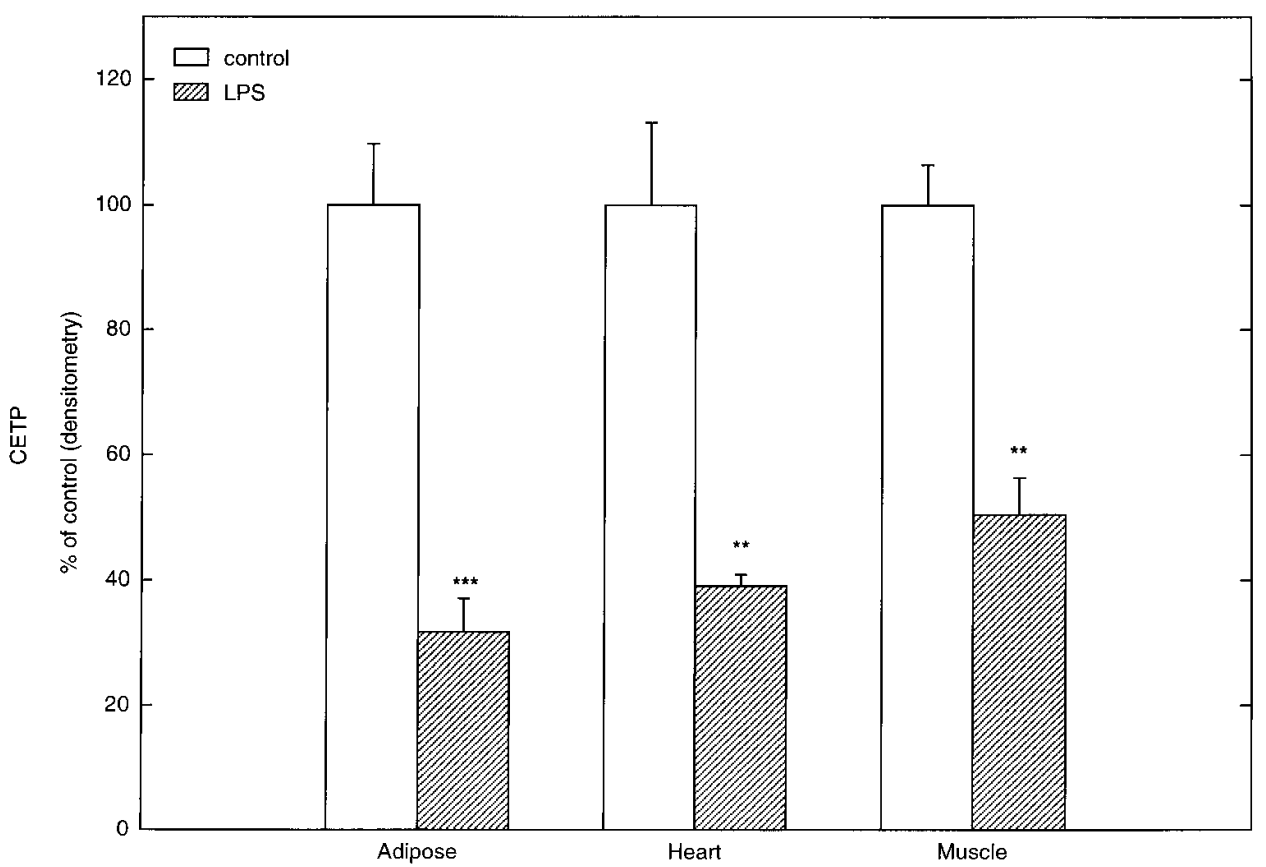

Figure 3. Effect of endotoxin on CETP protein levels in tissues. Syrian hamsters were injected i.p. with either saline (control, open bars) or $100 \mu \mathrm{g} / 100 \mathrm{~g}$ bw endotoxin (hatched bars). $16 \mathrm{~h}$ later the animals were killed, and the respective organs were collected. A portion $(1 \mathrm{~g})$ of the tissues were homogenized on ice with a Wheaton Dounce tissue grinder in $2 \mathrm{ml}$ of buffer containing $20 \mathrm{mM}$ sodium phosphate, $\mathrm{pH} 7.5$, $0.2 \mathrm{mM} \mathrm{NaCl}, 2 \%$ Triton X-100, $\mathrm{vol} / \mathrm{vol}, 1 \%$ sodium deoxycholate, $0.2 \%$ SDS, $2 \mathrm{mM}$ diethyl $p$-nitrophenyl phosphate, $0.2 \mu \mathrm{M}$ leupeptin, and $600 \mathrm{U} / \mathrm{ml}$ aprotinin (26). After 15-min incubation, the homogenate was centrifuged, and the clear infranatant used for determination of CETP by Western blotting. CETP was measured as described under Methods. Data are presented as mean \pm SEM, $n=5$. $* * P<0.005, * * * P<0.0005$ vs. control.

hepatic mRNA levels for CETP (19). It was therefore of interest to test whether corticosteroids would mimic the effects of endotoxin on CETP levels in hamsters, where regulation of the native gene can be studied and where serum levels of CETP are likely to be derived from extra hepatic sources. Hamsters were injected intraperitoneally with dexamethasone $(5 \mathrm{mg} / \mathrm{kg})$ or with saline (control), and plasma CETP and mRNA for CETP in adipose tissue were measured $16 \mathrm{~h}$ later. Dexamethasone did not affect serum levels of CETP in the Syrian hamsters (control (C): 100 $\pm 8.4 \%$, dexamethasone: $123 \pm 10.2 \%$ ) and increased mRNA levels for CETP in adipose tissue $(\mathrm{C}$ : $100 \pm 4.5 \%$; dexamethasone: $208 \pm 7.6 \%$ ), indicating that gluco- corticoids do not mediate the effects of endotoxin on CETP in the hamster.

As TNF and IL-1 mediate many of the effects of endotoxin, we next investigated whether administration of these cytokines individually or in combination affected serum levels of CETP. The doses of TNF and IL-1 used (17 $\mu \mathrm{g}$ and $1 \mu \mathrm{g} / 100 \mathrm{~g}$ bw, respectively) have been shown previously to alter lipid metabolism in Syrian hamsters (28) and to regulate apo J (29). In addition, TNF at this dose decreases hepatic LCAT mRNA levels and LCAT activity in Syrian hamsters (16). However, administration of the cytokines individually did not significantly affect serum CETP levels (Fig. 5). In contrast, the combination of

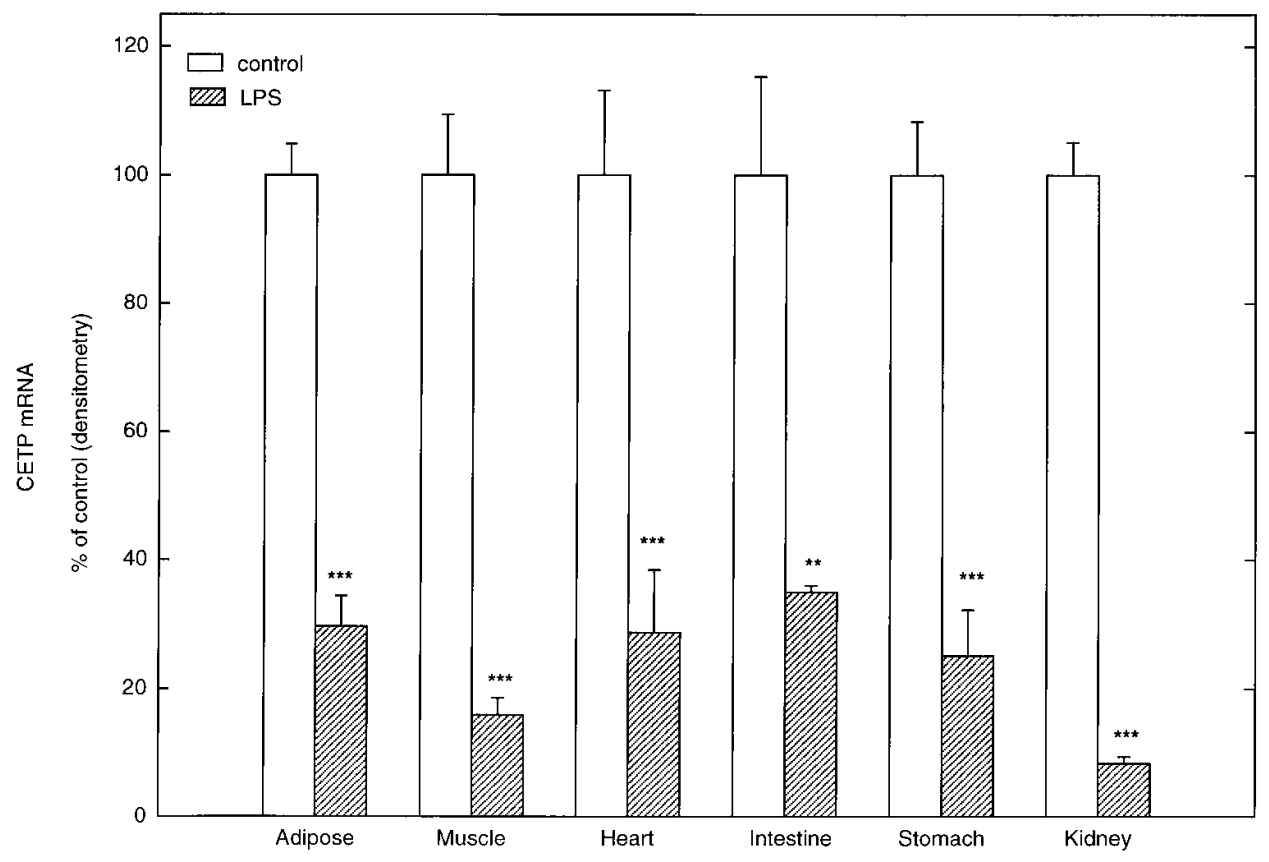

Figure 4. The effect of endotoxin on mRNA for CETP in extra hepatic tissues. Syrian hamsters were injected i.p. with either saline (open bars) or $100 \mu \mathrm{g} / 100 \mathrm{~g}$ bw endotoxin (hatched bars). $16 \mathrm{~h}$ later the animals were killed, and the respective tissues were collected. mRNA levels for CETP were measured as described in Methods. Data are presented as mean \pm SEM, $n=5$. $* * P<0.005, * * * P<0.0005$ vs. control. 


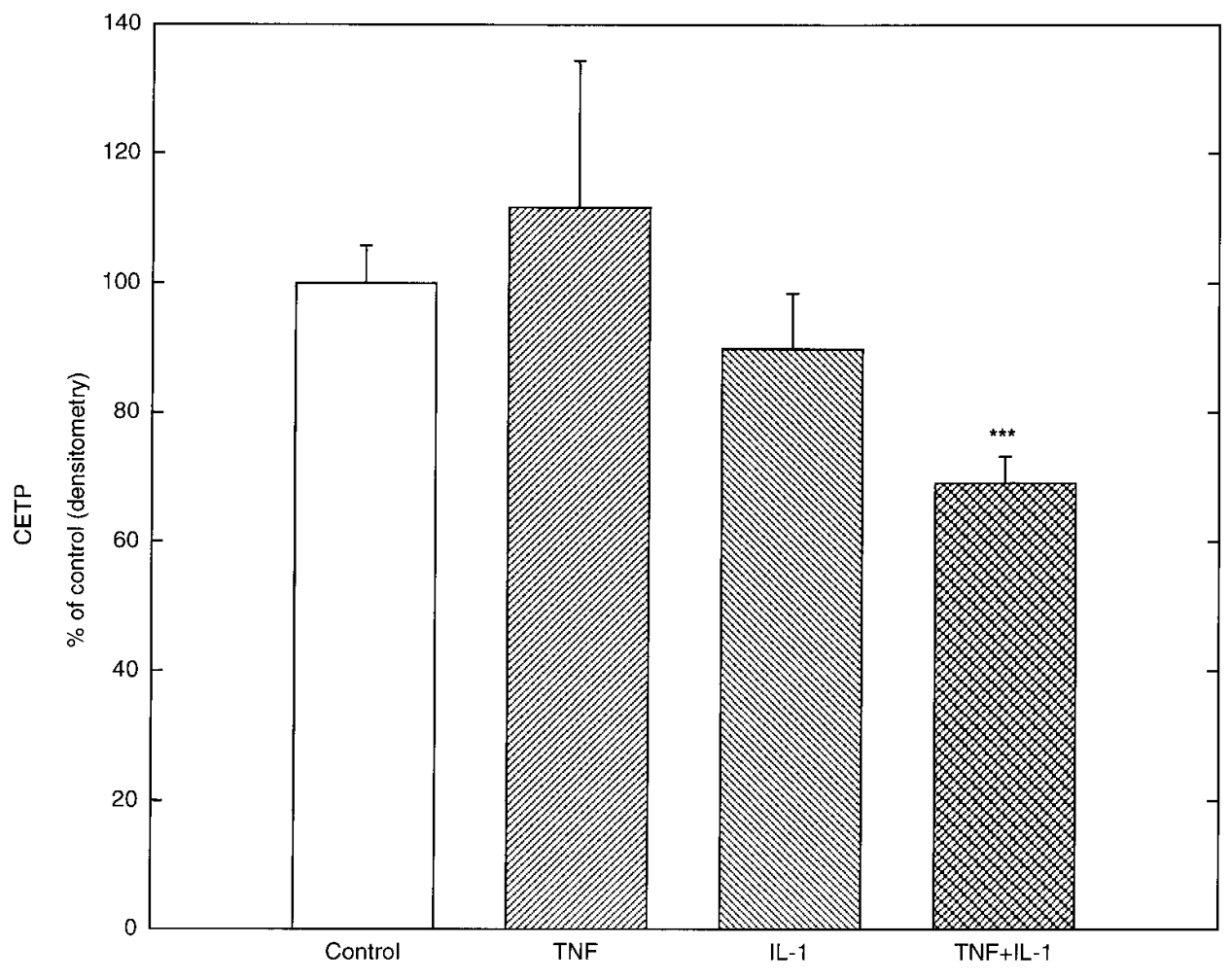

Figure 5. The effect of TNF and IL-1 on serum levels of CETP. Syrian hamsters were injected i.p. with saline, TNF (17 $\mu \mathrm{g} / 100 \mathrm{~g} \mathrm{bw})$, IL-1 (1 $\mu \mathrm{g} / 100 \mathrm{~g} \mathrm{bw})$, or TNF + IL-1 (17 $\mu \mathrm{g}$ $+1 \mu \mathrm{g} / 100 \mathrm{~g} \mathrm{bw}) .16 \mathrm{~h}$ later the animals were killed, and serum CETP was measured as described under Methods. Data are presented as mean \pm SEM, $n=5$. $* * * P<0.0005$ vs. control.
TNF + IL-1 significantly decreased serum levels of CETP to $69 \%$ of that of controls $16 \mathrm{~h}$ after their administration (Fig. 5). We have previously reported that the combination of TNF + IL-1 is more effective in mimicking the effects of endotoxin on cholesterol metabolism in Syrian hamsters $(28,29)$.

When TNF and IL-1 were administered alone at the doses described earlier, there was some effect of these cytokines in reducing the levels of mRNA for CETP in a few of the tissues studied (Table I). However, when TNF + IL-1 were administered together they were much more effective than the individual cytokines; the combination reduced mRNA levels for CETP in all the tissues studied by $>75 \%$ (Fig. 6). Thus simultaneous administration of TNF and IL-1 together is more effective at decreasing both serum protein levels and tissue mRNA levels of CETP than either cytokine individually. The combination mimics LPS treatment.

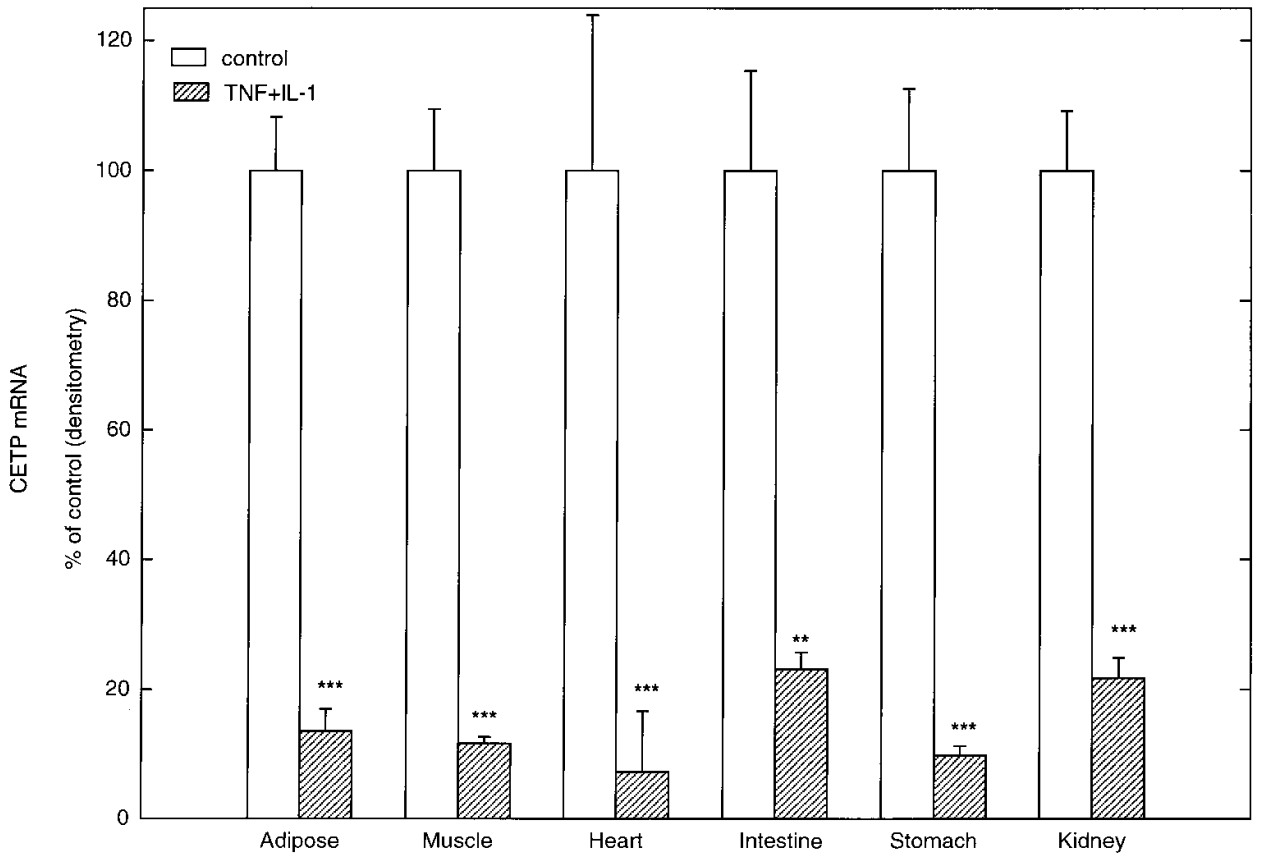

Figure 6. The effect of TNF + IL-1 on mRNA for CETP in extra hepatic tissues. Syrian hamsters were injected i.p. with either saline (open bars) or $17 \mu \mathrm{g}$ TNF $+1 \mu \mathrm{g} \mathrm{IL}-1 / 100 \mathrm{~g}$ bw (hatched bars). $16 \mathrm{~h}$ later the animals were killed, and the respective tissues were collected. mRNA levels for CETP were measured as described in Methods. Data are presented as mean \pm SEM, $n+5$. $* * P<0.005, * * * P<0.0005$ vs. control. 
Table I. Effects of TNF or IL-1 on mRNA Levels for CETP in Peripheral Tissues in Syrian Hamsters

\begin{tabular}{lcc}
\hline \multirow{2}{*}{ Tissue } & \multicolumn{2}{c}{ Percentage of control } \\
\cline { 2 - 3 } & \multicolumn{1}{c}{ TNF } & IL-1 \\
\hline Adipose tissue & $17 \mu g / 100 \mathrm{~g} \mathrm{bw}$ & $1 \mu \mathrm{g} / 100 \mathrm{~g} \mathrm{bw}$ \\
Muscle & $64 \pm 8.6$ & $78 \pm 10$ \\
Heart & $40 \pm 4.4^{*}$ & $43 \pm 7.1^{\ddagger}$ \\
Intestine & $40 \pm 6.6^{*}$ & $40 \pm 3.8^{\ddagger}$ \\
Stomach & $28 \pm 3.7^{*}$ & $89 \pm 25$ \\
Kidney & $38 \pm 7.2^{\ddagger}$ & $62 \pm 6.6^{*}$ \\
& $47 \pm 4.0^{*}$ & $91 \pm 12$ \\
\hline
\end{tabular}

Animals were injected i.p. with either saline (controls), TNF $(17 \mu \mathrm{g} / 100$ $\mathrm{g}$ bw), or IL-1 (1 $\mu \mathrm{g} / 100 \mathrm{~g}$ bw). $16 \mathrm{~h}$ later the animals were killed, and the respective tissues were removed. RNA was extracted and CETP mRNA measured as described in Methods. Data are presented as mean \pm SEM with $n=5$. ${ }^{*} P<0.02$ and ${ }^{\ddagger} P<0.05$ vs. control.

\section{Discussion}

The data presented in this paper demonstrate that endotoxin and cytokines decrease CETP levels in the serum and CETP protein and mRNA levels in extra hepatic tissues in Syrian hamsters. Circulating CETP levels began to decrease rapidly after administration of endotoxin and progressively decreased with time for at least $48 \mathrm{~h}$. This pattern of early, progressive, and sustained effect after single administration of endotoxin is common. The changes in serum triglyceride levels after endotoxin administration follow a similar pattern in the opposite direction. $2 \mathrm{~h}$ after endotoxin administration, serum triglyceride levels are increased (30) and continue to increase with time (16), reaching levels fivefold higher than control levels at $48 \mathrm{~h}$ (C: $100 \pm 19$; $\%$ endotoxin: 509 $\pm 40 \%$; unpublished observations by this laboratory). The changes in serum triglyceride levels are thus a mirror image of the changes in CETP levels after endotoxin administration. The changes in HDL cholesterol levels follow a different pattern decreasing at 4 and $8 \mathrm{~h}$ (16) but returning to control levels by $48 \mathrm{~h}$ after endotoxin administration (C: $100 \pm 5.6 \%$; endotoxin: $93 \pm 8.7 \%$; unpublished observations by this laboratory).

The decrease in HDL cholesterol levels may be linked to the increase in serum triglycerides as hypertriglyceridemia is often associated with decreased HDL cholesterol levels (3133). CETP facilitates the exchange of cholesterol ester in HDL for VLDL triglyceride, thus the abundant VLDL triglyceride in hypertriglyceridemia can promote this exchange and contribute to the decrease in HDL cholesterol levels. In fact, hypertriglyceridemia in humans is often associated with increased CETP activity (34). In contrast, the endotoxin-induced hypertriglyceridemia in the hamsters, although associated with decreased HDL cholesterol levels, is associated with a marked decrease in CETP levels. Endotoxin thus appears to have an effect on CETP that is independent of the hypertriglyceridemic effect and potentially serves to prevent or blunt the decrease in HDL cholesterol levels. That decreasing CETP levels may increase HDL cholesterol levels is suggested by an inverse relationship between plasma CETP levels and HDL cholesterol levels in CETP-deficient humans $(35,36)$. In addition, overexpression of CETP in transgenic mice causes decreased
HDL cholesterol levels $(37,38)$, and cholesterol feeding of hamsters which increases CETP activity is associated with decreased HDL cholesterol levels (20).

The decrease in CETP is a sensitive response to endotoxin, with ID $_{50}$ between 0.1 and $1 \mu \mathrm{g} / 100 \mathrm{~g}$ bw. These doses of endotoxin are far below the doses required to cause death in rodents in our laboratory. We have previously demonstrated that the alterations in lipid metabolism are among the most sensitive host responses to endotoxin. For example, in Syrian hamsters, endotoxin at $0.1 \mu \mathrm{g} / 100 \mathrm{~g}$ bw increases serum cholesterol, triglyceride, and apo $\mathrm{J}$ levels while decreasing serum LCAT activity $(4,16,29)$. The increase in apo $\mathrm{J}$ and decrease in LCAT activity were preceded by increased and decreased mRNA levels for these proteins. However, higher doses of endotoxin $(10 \mu \mathrm{g} / 100 \mathrm{~g} \mathrm{bw})$ are required for decreasing HDL cholesterol levels (16). A lower dose of endotoxin is able to decrease CETP levels compared to what is needed to decrease HDL cholesterol levels.

Endotoxin-induced decreases in circulating CETP levels may be mediated at least in part by marked decreases in mRNA levels for CETP in extra hepatic tissues and decreases in CETP protein levels in adipose tissue, muscle and heart. Adipose tissue, muscle, and heart are abundant sources of mRNA for CETP and adipose tissue mRNA levels strongly correlate with plasma CETP concentrations $(20,26)$. Thus the decrease in CETP protein and mRNA levels in adipose and other extra hepatic tissues is likely to explain the decrease in plasma CETP seen here in response to endotoxin. However, it is possible that plasma CETP levels are also affected by changes in translation, secretion, or clearance of CETP.

The effects of endotoxin on serum levels of CETP in the present study are consistent with the reported results of Masucci-Magoulas et al. (19), who demonstrated that endotoxin reduces plasma CETP levels and hepatic mRNA levels for CETP in mice overexpressing the human CETP gene. However, there are significant differences in the results from the two studies. First, the decrease in hepatic mRNA levels for CETP in the transgenic mice was transient, with mRNA levels returning to control levels by $48 \mathrm{~h}$ after the higher dose of endotoxin $(200 \mu \mathrm{g})$ and actually being significantly increased after lower doses of endotoxin $(25 \mu \mathrm{g})$. Here we found the decrease in CETP to be progressive over $48 \mathrm{~h}$. Second, in contrast to our results in the hamster, in the transgenic mice endotoxin increased mRNA levels for CETP in extra hepatic tissues. Endotoxin thus decreased mRNA levels for CETP in the liver, the major contributor to plasma CETP in humans, but increased mRNA levels for CETP in other tissues. In the present study in hamsters, where extra hepatic tissues are a major source of plasma CETP, endotoxin decreased mRNA for CETP in these tissues.

Third, Masucci-Magoulas et al. (19) demonstrated that glucocorticoids mediated the effects of endotoxin on CETP levels in the transgenic mice. Although glucocorticoids may mimic some effects of endotoxin, dexamethasone administration (5 $\mathrm{mg} / \mathrm{kg}$ ) did not produce the same effect as endotoxin on CETP in Syrian hamsters, suggesting that in hamsters glucocorticoids do not mediate this effect of endotoxin. There are several possible reasons for the disparate results with regard to glucocorticoids. For example, many aspects of the acute phase response are species specific, and it is possible that there are species differences in the mechanisms by which endotoxin acts in hamsters and humans/mice. In fact, we have previously demon- 
strated that the effects of endotoxin on lipid metabolism in mice and rats may have different mediators, with TNF being an important mediator of endotoxin-induced hypertriglyceridemia in mice but not in rats, where catecholamines seem to be of primary importance $(3,39)$. Furthermore, the difference in mediators of the endotoxin-induced decrease in CETP could be due to the fact that in the hamster serum levels of CETP are derived from extra hepatic tissues, whereas in humans serum levels of CETP are of hepatic origin. Glucocorticoids are known to regulate genes differently in the liver compared to extra hepatic tissues.

TNF and IL-1 may mediate the effects of endotoxin on CETP in the Syrian hamsters. Although ineffective when administered alone, when administered together these cytokines decreased CETP levels in the serum and mRNA levels for CETP in extra hepatic tissues. While TNF and IL-1 alone may mimic some of the effects of endotoxin the combination is more effective. For example TNF + IL-1 increase serum triglyceride levels, serum cholesterol levels, and decrease HDL cholesterol levels in Syrian hamsters more effectively when administered together than either cytokine alone (unpublished data from this laboratory) (28). In addition, the administration of TNF + IL-1 together acts synergistically to produce hemodynamic shock (40). Experiments with inhibitors of hamster cytokines will be necessary to directly demonstrate whether TNF and IL-1 mediate the effects of LPS on CETP in hamsters. In mice, TNF mediates most of the effects of LPS on lipid metabolism (3).

Endotoxin-induced decreases in plasma CETP may help to preserve HDL levels after exposure to endotoxin. In addition to the decrease in CETP levels, a decrease in hepatic lipase activity (7-10) may also serve to maintain HDL cholesterol levels by decreasing formation of remnant $\mathrm{HDL}_{2}$ and thus decreasing clearance of HDL. Preserving HDL cholesterol levels during infection and inflammation may be important because of the ability of HDL to prevent the toxic effects of endotoxin (41-43) and reduce oxidative stress $(44,45)$. Maintaining HDL cholesterol levels may also be important for delivery of cholesterol to peripheral tissues that may have increased needs for cholesterol during infection and inflammation. Increased apoSAA on HDL during infection and inflammation may lead to increased uptake of cholesterol by peripheral cells involved in the immune response as apoSAA-rich HDL have increased affinity for macrophages and decreased affinity for hepatocytes (6). These changes may be analogous to the increased glucose utilization in macrophage-rich tissues after administration of endotoxin (46-48).

In summary, endotoxin and cytokines decrease serum levels and extra hepatic protein and mRNA levels for CETP in Syrian hamsters. The decrease in CETP may serve to maintain HDL cholesterol levels under conditions where they would otherwise be significantly decreased through exchange for abundant VLDL triglyceride. Maintaining HDL cholesterol levels during infection and inflammation may be important because HDL protects against the toxic effects of endotoxin and may serve as a source of cholesterol for cells involved in the immune response or tissue repair.

\section{Acknowledgments}

This work was supported by grants from the Research Service of the Department of Veterans Affairs and the National Institutes of Health (DK-40990).

\section{References}

1. Mackiewicz, A., I. Kushner, and H. Baumann, editors. 1993. Acute Phase Proteins. Molecular Biology, Biochemistry, and Clinical Applications. CRC Press. Boca Raton, FL.

2. Hardardóttir, I., C. Grünfeld, and K.R. Feingold. 1994. Effects of endotoxin and cytokines on lipid metabolism. Curr. Opin. Lipidol. 5:207-215.

3. Memon, R.A., C. Grunfeld, A.H. Moser, and K.R Feingold. 1993. Tumor necrosis factor mediates the effects of endotoxin on cholesterol and triglyceride metabolism in mice. Endocrinology. 132:2246-2253.

4. Feingold, K.R., I. Hardardóttir, R. Memon, E.J.T. Krul, A.H. Moser, J.M. Taylor, and C. Grunfeld. 1993. Effect of endotoxin on cholesterol biosynthesis and distribution in serum lipoproteins in syrian hamsters. J. Lipid Res. 34: 2147-2158.

5. Hoffman, J.S., and E.P. Benditt. 1983. Plasma clearance kinetics of the amyloid-related high density lipoprotein apoprotein, serum amyloid protein (apoSAA), in the mouse. Evidence for rapid apoSAA clearance. J. Clin. Invest. 71:926-934.

6. Kisilevsky, R., and L. Subrahmanyan. 1992. Serum amyloid A changes high density lipoprotein's cellular affinity. A clue to serum amyloid A's principal function. Lab. Invest. 66:778-785.

7. Kawakami, M., T. Murase, H. Itakura, N. Yamada, N. Ohsawa, and F. Takaku. 1986. Lipid metabolism in endotoxic rats: decrease in hepatic triglyceride lipase activity. Microbiol. Immunol. 30:849-854.

8. Magilavy, D.B., R. Zhan, and DD. Black. 1993. Modulation of murine hepatic lipase activity by exogenous and endogenous Kupffer-cell activation. Biochem. J. 292:249-252.

9. Meraïhi, Z., O. Lutz, J.-M. Scheftel, A. Frey, J. Ferezou, and A.C. Bach 1991. Decreased lypolytic activity in tissues during infectious and inflammatory stress. Nutrition. 7:93-97.

10. Sammalkorpi, K., V. Valtonen, Y. Kerttula, E. Nikkilä, and M.-R. Taskinen. 1988. Changes in serum lipoprotein pattern induced by acute infections. Metabolism. 37:859-865.

11. Barrans, A., X. Collet, R. Barbaras, B. Jaspard, J. Manent, C. Vieu, H. Chap, and B. Perret. 1994. Hepatic lipase induces the formation of pre- $\beta 1$ high density lipoprotein (HDL) from triacylglycerol-rich HDL2. J. Biol. Chem. 269: 11572-11577.

12. Castro, G.R., and C.J. Fielding. 1988. Early incorporation of cellderived cholesterol into pre-beta-migrating high-density lipoprotein. Biochemistry. 27:25-29.

13. Francone, O.L., A. Gurakar, and C. Fielding. 1989. Distribution and functions of lecithin:cholesterol acyltransferase and cholesterol ester transfer protein in plasma lipoproteins. Evidence for a functional unit containing these activities together with apolipoproteins A-I and D that catalyzes the esterification and transfer of cell-derived cholesterol. J. Biol. Chem. 264:7066-7072.

14. Ettinger, W.H., L.D. Miller, J.J. Albers, T.K. Smith, and J.S. Parks. 1990. Lipopolysaccharide and tumor necrosis factor cause a fall in plasma concentration of lecithin:cholesterol acyltransferase in cynomolgus monkeys. $J$. Lipid Res. 31:1099-1107.

15. Auerbach, B.J., and J.S. Parks. 1989. Lipoprotein abnormalities associated with lipopolysaccharide-induced lecithin:cholesterol acyltransferase and lipase deficiency. J. Biol. Chem. 264:10264-10270.

16. Ly, H., O.L. Francone, C.J. Fielding, J.K. Shigenaga, A.H. Moser, C. Grunfeld, and K.R. Feingold. 1995. Endotoxin and TNF lead to reduced plasma LCAT activity and decreased hepatic LCAT mRNA levels in Syrian hamsters. J. Lipid Res. 36:1254-1263.

17. Tall, A.R. 1993. Plasma cholesteryl ester transfer protein. J. Lipid Res. 34:1255-1274.

18. Fielding, C.J. 1993. Lipid transfer proteins: catalysts, transmembrane carriers and signalling intermediates for intracellular and extracellular lipid reactions. Curr. Opin. Lipidol. 4:218-222.

19. Masucci-Magoulas, L., P. Moulin, X.C. Jiang, H. Richardson, A. Walsh, J.L. Breslow, and A. Tall. 1995. Decreased cholesteryl ester transfer protein (CETP) mRNA and protein and increased high density lipoprotein after lipopolysaccharide administration in human CETP transgenic mice. J. Clin. Invest. 95:1587-1594.

20. Quinet, E.M., P. Huerta, D. Nancoo, A.R. Tall, Y.L. Marcel, and R. McPherson. 1993. Adipose tissue cholesteryl ester transfer protein mRNA in response to probucol treatment: cholesterol and species dependence. J. Lipid Res. 34:845-852.

21. Quig, D.W., C.M. Arbeeny, and D.B. Zilversmit. 1991. Effects of hyperlipidemias in hamsters on lipid transfer protein activity and unidirectional cholesteryl ester transfer in plasma. Biochim. Biophys. Acta. 1083:257-264.

22. Au-Young, J., and C.J. Fielding. 1992. Synthesis and secretion of wildtype and mutant human plasma cholesteryl ester transfer protein in baculovirus-transfected insect cells: The carboxyl-terminal region is required for both lipoprotein binding and catalysis of transfer. Proc. Natl. Acad. Sci. USA. 89: 4094-4098.

23. Chomczynski, P., and N. Sacchi. 1987. Single-step method of RNA isolation by acid guanidinium thiocyanate-phenol-chloroform extraction. Anal. Biochem. 162:156-159.

24. Morrow, J.F., R.S. Steraman, C.G. Peltzman, and D.A. Potter. 1981. In- 
duction of hepatic synthesis of serum amyloid A protein and actin. Proc. Natl. Acad. Sci. USA. 78:4718-4722.

25. Clarke, C.F., P.A. Edwards, S.-F. Lan, R.D. Tanaka, and A.M. Fogelman. 1983. Regulation of 3-hydroxy-3-methylglutaryl-coenzyme A reductase mRNA levels in rat liver. Proc. Natl. Acad. Sci. USA. 80:3305-3308.

26. Jiang, X.C., P. Moulin, E. Quinet, I.J. Goldberg, L.K. Yacoub, L.B. Agellon, D. Compton, R. Schnitzer-Polokoff, and A. Tall. 1991. Mammalian adipose tissue and muscle are major sources of lipid transfer protein in mRNA. J. Biol. Chem. 266:4631-4639.

27. Baumann, H., C. Richards, and J. Gauldie. 1987. Interaction among hepatocyte-stimulating factors, interleukin-1 and glucocorticoids for regulation of acute phase plasma proteins in human hepatoma (HepG2) cells. J. Immunol. 139:4122-4128.

28. Hardardóttir, I., A.H. Moser, R. Memon, C. Grünfeld, and F.R. Feingold. 1994. Effects of TNF, IL-1, and the combination of both cytokines on cholesterol metabolism in Syrian hamsters. Lymphokine Cytokine Res. 13:161-166.

29. Hardardóttir, I., S.T. Kunitake, A.H. Moser, W.T. Doerrler, J.H. Rapp, C. Grünfeld, and K.R. Feingold. 1994. Endotoxin and cytokines increase hepatic messenger RNA levels and serum concentrations of apolipoprotein $\mathbf{J}$ (Clusterin) in Syrian hamsters. J. Clin. Invest. 94:1304-1309.

30. Feingold, K.R., I. Staprans, R.A. Memon, A.H. Moser, J.K. Shigenaga, W. Doerrler, C.A. Dinarello, and C. Grunfeld. 1992. Endotoxin rapidly induces changes in lipid metabolism that produce hypertriglyceridemia: low doses stimulate hepatic triglyceride production while high doses inhibit clearance. J. Lipid Res. 33:1765-1776.

31. Goldberg, I.J., W.S. Blaner, T.M. Vanni, M. Moukides, and R. Ramakrishnan. 1990. Role of lipoprotein lipase in the regulation of high density lipoprotein apolipoprotein metabolism. Studies in normal and lipoprotein lipaseinhibited monkeys. J. Clin. Invest. 86:463-473.

32. Albrink, M.J., R.M. Krauss, F.T. Lindgren, and V.D. Groeben. 1980. Inter correlations among high density lipoprotein, obesity and triglycerides in a normal population. Lipids. 15:668-678.

33. Schaefer, E.J., R.I. Levy, D.W. Anderson, R.N. Danner, J.H.B. Brewer, and W.C. Blackwelder. 1978. Plasma-triglycerides in regulation of H.D.L.-cholesterol levels. Lancet. ii:391-392.

34. Iglesias, A., J.A. Contreras, M. Marínes-Pardo, A. Entrala, E. Herrera, and M.A. Lasunción. 1993. Cholesteryl ester transfer activity in lipoprotein lipase deficiency and other primary hypertriglyceridemias. Clin. Chim. Acta. 221: 73-89.

35. Yamashita, S., Y. Matsuzawa, M. Okazaki, H. Kato, T. Yasugi, H. Akioka, K. Hirano, and S. Tarui. 1988. Small polydisperse low density lipoproteins in familial hyperalphalipoproteinemia with complete deficiency of cholesteryl ester transfer activity. Atherosclerosis. 70:7-12.

36. Brown, M.L., A. Inazu, C.B. Hesler, L.B. Agellon, C. Mann, M.E. Whitlock, Y.L. Marcel, R.W. Milne, J. Koizumi, H. Mabuchi, R. Takeda, and A.R. Tall. 1989. Molecular basis of lipid transfer protein deficiency in a family with increased high-density lipoproteins. Nature (Lond.). 342:448-451.

37. Agellon, L.B., A. Walsh, T. Hayek, P. Moulin, X.C. Jiang, S.A. Shelanski, J.L. Breslow, and A.R. Tall. 1991. Reduced high density lipoprotein cholesterol in human cholesteryl ester transfer protein transgenic mice. J. Biol. Chem. 266:10796-10801.

38. Hayek, T., T. Chajek-Shaul, A. Walsh, L.B. Agellon, P. Moulin, A.R.
Tall, and J.L. Breslow. 1992. An interaction between the human cholesteryl ester transfer protein (CETP) and apolipoprotein A-I genes in transgenic mice results in a profound CETP-mediated depression of high density lipoprotein cholesterol levels. J. Clin. Invest. 90:505-510.

39. Nonogaki, K., A.H. Moser, K.R. Feingold, and C. Grunfeld. 1994. $\alpha$-adrenergic receptors mediate the hypertriglyceridemia induced by endotoxin, but not tumor necrosis factor, in rats. Endocrinology. 135:2644-2650.

40. Okusawa, S., J.A. Gelfand, T. Ikejima, R.J. Connolly, and C.A Dinarello. 1988. Interleukin 1 induces a shock-like state in rabbits. Synergism with tumor necrosis factor and the effect of cyclooxygenase inhibition. J. Clin. Invest. 81:1162-1172.

41. Levine, D.M., T.S. Parker, T.M. Donnelly, A. Walsh, and A.L. Rubin. 1993. In vivo protection against endotoxin by plasma high density lipoprotein. Proc. Natl. Acad. Sci. USA. 90:12040-12044.

42. Parker, T.S., D.M. Levine, J.C. Chang, J. Laxer, C.C. Coffin, and A.L. Rubin. 1995. Reconstituted high-density lipoprotein neutralizes gram-negative bacterial lipopolysaccharides in human whole blood. Infect. Immun. 63:253258

43. Harris, H.W., C. Grunfeld, K.R. Feingold, and J.H. Rapp. 1990. Human very low density lipoproteins and chylomicrons can protect against endotoxininduced death in mice. J. Clin. Invest 86:696-702.

44. Steinbrecher, U.P., J.L. Witztum, S. Parthasarathy, and D. Steinberg. 1987. Decrease in reactive amino groups during oxidation or endothelial cell modification of LDL. Arteriosclerosis. 7:135-143.

45. Parthasarathy, S., J. Barnett, and L.G. Fong. 1990. High-density lipoprotein inhibits the oxidative modification of low-density lipoprotein. Biochim. Biophys. Acta. 1044:275-283.

46. Spolarics, Z., P.H. Pekala, G.J. Bagby, and J.J. Spitzer. 1993. Brief endotoxemia markedly increases expression of GLUT1 glucose transporter in Kupffer, hepatic endothelial and parenchymal cells. Biochem. Biophys. Res. Commun. 193:1211-1215.

47. Spolarics, Z., and J.J. Spitzer. 1995. Acute endotoxin tolerance is accompanied by stimulated glucose use in macrophage rich tissues. Biochem. Biophys. Res. Commun. 211:340-346.

48. Orlinska, U., and R.C. Newton. 1993. Role of glucose in interleukin-1 beta production by lipopolysaccharide-activated human monocytes. J. Cell. Physiol. 157:201-208.

49. Zamir, O., P.O. Hasselgren, D.V. Allmen, and J.E. Fishcer. 1993. The effect of interleukin-1 $\alpha$ and the glucocorticoid receptor blocker RU 38486 on total and myofibrillar protein breakdown in skeletal muscle. J. Surg. Res. 50: 579-583.

50. Zamir, O., P.O. Hasselgren, D. Allmen, and J.E. Fischer. 1993. In vivo administration of interleukin-1 $\alpha$ induces muscle proteolysis in normal and adrenalectomized rats. Metabolism. 42:204-208.

51. Zamir, O., P.O. Hasselgren, S.L. Kunkel., J. Frederick, T. Higashiguchi, and J.E. Fischer. 1992. Evidence that tumor necrosis factor participates in the regulation of muscle proteolysis during sepsis. Arch. Surg. 127:170-174.

52. Hall-Angeras, M., U. Angeras, O. Zamir, P.O. Hasselgren, and J.E. Fischer. 1990. Interaction between corticosterone and tumor necrosis factor stimulated protein breakdown in rat skeletal muscle, similar to sepsis. Surgery. 108:460-466. 